\title{
From Tripitaka to Isan Phaya: On Common Characteristics of Existence
}

\author{
Asst. Prof. Dr. Amporn Sa-ngiamwibool, Shinawatra University, Thailand \& \\ Assoc. Prof. Dr. Somchai Srinok, Mahachulalongkornrajavidyalaya University, Thailand \\ amporn_kai@yahoo.com
}

\begin{abstract}
Phaya, or a philosophical verse of local people in northeastern Thailand or locally called Isan whose culture is intimate to that of Lao People's Democratic Republic, is believed to be influenced by Buddhist Dhamma. It is, therefore, interesting to analyze how the local Isan philosophers borrowed ideas from the source and composed this valuable cultural heritage, with a specific focus on the theme of common characteristics of existence, consisting of anicca (impermanence), dukkha (suffering) and anatta (non-self). 252 existing verses were explored with a focus on common characteristics of existence. The findings revealed that the essence of the verses was literally borrowed from the source, Tripitaka, and figuratively adjusted for literary purposes. Implications of this analysis reassure that phayas are a truly cultural and religious heritage for the two countries.
\end{abstract}

Keywords: Tripitaka, Isan phaya, common characteristics of existence

\section{Introduction}

The value of literature, both local and traditional, is enormous and greatly contributing to life on various aspects (e.g. inspiration, emotion, art, culture, history, imagination, use of language, knowledge and wisdom, and critical thinking) (Bunnotok, 1984; Fakkong, 1987; Manyaporn, 1979; Mutramata, 1974; Tangkawee, 1985) and beneficial to individuals as well as the society (Bunnotok, 1982, 1983, 1984). Literature influences the society and is influenced by it. The lifestyle of the people is also built upon it (Kuntawee, 1986). One of the local literary works that influence the lifestyle of local people is phaya, or a philosophical verse of local people in northeastern Thailand or locally called Isan where their cultural heritage has been traditionally passed down from generations to generations. Isan phaya is believed to be influenced by Buddhist dharma (e.g. Thanapaññõ, 2011) as it teaches a sense of duty to adhere to and maintain the
Buddhist dharma (e.g. precepts) in order to achieve good results in this life and the next one (Kuntawee, 1986). Like other genres of literature, it affects the local people individually and socially (e.g. Suvannasri, 2011) as it deals with a philosophy of life, lifestyle, social traditions, religious faiths and cultural values that have been passesd on from generations to generations through the local culture and language of the Isan people. Any studies of Isan phaya are very interesting and worth trying because this local verse is socially engaged with Buddhism and, therefore, becomes universal to some extent.

Despite its significance, there have been a limited number of research studies concerning local Isan literature. Research specifically on Isan phaya is scanty (e.g. Suvannasri, 2011; Preecha, 1985; Thanapaññõ, 2011) and most of this limited number focus on phaya and the local people in general (Suvannasri, 2011; Preecha, 1985). Even scantier is Isan phaya influenced by 
Buddhist principles (e.g. Thanapaññõ, 2011). The following are some research studies on phaya.

On the condition of phaya at present, Suvannasri (2011) studied the values, existence and transmission of Isan phaya. The purposes of the study were to: 1) analyze values of phaya, 2) analyze the existence of phaya in the current context of Isan community, and 3) present ways of phaya transmission. The research was based on triangulation and the instruments for the data elicitation included documentary research, field trip, in-depth interviews, nonparticipatory observations and panel discussions. The data were quantitatively and qualitatively analyzed to draw the conclusion of the study which were finally verified by phaya experts for validity check. The results of the study revealed the following research findings. First, the values of 283 phaya verses in this study fell into these two parts: individual persons and the society. The contents on persons were concerned with these topics, ranging from the most to the least: self-development, occupation and social development respectively. In details, the contents on the society were concerned with family and social institutes (e.g. political, economic, educational and religious). Second, of the 283 phaya verses that are still exist, consisting of 31 unused, 252 using and 12 changed. They were written in various forms (namely, radio and television programs academic texts, verses, preachments, conversations in welcoming parties, BaisriSue-Khuan ceremonies, lectures and through the Internet). Lastly, there were four means to transmit phayas: 1) school curriculum, 2) organizations engaging in local culture, 3) community learning center, and 4) youth and new generation engagement.

On phaya and lifestyle, Preecha (1985) studied the contents of Isan phayas and classified them into 13 categories:

1) Eating:

“กินผู้เดียวบ่ปันหมู่ งูเขียวเกี้ยว"

(Sharing food to others can save one from snakes.)
2) Distress:

“ลูกตายเสีย เมียตายจาก

พรากพี่น้องหนีไปไกล ลงไปไทยค้างัวต่าง

ผัวเมียฮ้างปะกัน ไปนอนวันพรากพี่

น้อง ป้องหมูน้อยลงไปขาย

พ่อแม่ตายแสนคึดฮอด

บ่มีเมียนอนกอดอยู่ผู้เดียว

เทียวทางหลงยามค่ำ ตกฮำฟ้อฮ้อง

เจ็บปวดท้องบ่มียา"

(The loss of beloved children and wife, the separation from siblings and spouses, children, the distance from home for trade, the missing dead parents, sleeping alone without the loved one, getting lost at night time, rain and thunder storms, pain without medication - all these are painful, lonely and helpless.)

3) Happiness:

"อยากมีหลายมันไฮ้ อยากได้หลายมันตาย"

(Giving is happiness while taking is suffering.)

4) Self:

"เพิ่นซังโต อย่าโง่ซังตอบ"

(Smart people should ignore hatred.)

5) People:

“ลูกที่ดีควรต้อง นบนอบบังคม

คุณบิดามารดา ผู้พาเพียรสร้าง"

(Children should respect and honor their parents for their devotion.)

6) Work:

"ตื่นแต่เช้ากินยอดฟ้า

ตื่นสวยกินขวยขี้ไก่โป่'"

(Early birds catch the worms; otherwise, catch nothing.)

7) Carelessness:

"อย่าเซื่อใจทาง อย่าวางใจคน มันจนใจโต"

(Trust neither an unknown road nor an unknown person.) 
8) Merit and sin:

"บุญบาปนี้เป็นคู่คือเงา

เงานั้นไปตามเฮาซู่ยามบ่มีเว้น"

(Merit and sin are like the shadows that always follow us.)

9) Relationship:

"ตกหมู่แฮ้งเป็นแฮ้ง ตกหมู่กาเป็นกา"

(Feathers of the same flock together.)

10) Wisdom:

“ได้ยินด้วยหู ได้ดูด้วยตา

ให้พิจารณาด้วยใจ ฮู้แล้วอย่างเลิง"

(What is heard or seen needs to be considered by heart to see the truth and stay calm when you realized it.)

11) Learning:

"เฮียนให้สุด ขุดให้เถิง"

(Master all what you have learnt.)

12) Dharma puzzle:

"อยากกินน้ำแซบ ให้ขุดน้ำบ่อหิน

อยากกินน้ำแซบ ให้ขุดน้ำบ่อหิน

อยากกินน้ำแซบ ให้ขุดน้ำบ่อหิน"

(If you wish to drink pure water, dig under the rock. If you wish to do business, be moral. If you wish to go to heaven, kill yourself / your ego.)

13) Miscellaneous:

"ใกล้ไฟมันฮ้อน ใกล้ค้อนมันเจ็บ"

(Get burnt when you are close to fire and get hurt when you are close to a hammer.)

On phaya and Buddhist principles, Thanapaññõ (Settha) (2011) aimed to: 1) study the history and development of Isan proverbs, 2) compare both aspects, and 3) study the relationship between Isan proverbs and Buddhist proverbs. This was documentary study. The results of the study revealed the following findings. First, phaya was the proverb which was spoken and written by Isan scholars to teach persons to adhere to the Buddhist principles in order to be well-peformed and live a happy life. It was divided into two groups: phaya kreu or proverbs of a long sentence, and phaya kom, or proverbs of short words. Whether they are long or short, the contents fall into 3 categories: good proverbs, loving couple talks, and puzzle proverbs. Second, the proverbs were in harmony with Buddhist proverbs in four main ways: 1) the practice of persons (e.g. the education), 2) the relation of persons with persons (e.g. the six directions), 3 ) association or the relation of persons with the nature (e.g. defiling of persons with the nature), and 4) relation of persons with supernatural power (e.g. bases of meritorious action, evil, carelessness, and non-carelessness for daily life). Finally, Buddhist proverbs were divided into thirteen groups: 1) self, 2) person, 3) action, 4) work, 5) carelessness, 6) vices and virtues, 7) association, 8) happiness and suffering, 9) donation, 10) precepts, 11) diligence, 12) death and 13) miscellaneous. Isan phaya proverbs could be synthesized into each of the equivalent Buddhist proverbs. Both were almost exactly alike and aimed at personal development and socialization.

It could be concluded that, based on the review of local Isan literature in general and phayas in particular, Isan phayas fall into two categories: lifestyle phayas and Buddhist phayas. On lifestyle, phaya is one of the strategies that are intended to socialization. As reflected, the contents of phayas are primarily concerned with how to lead a decent life, especially refraining from all evils. These lifestyle phayas include the 13 types as indicated in the work of Preecha (1985) and Thanapaññõ (Settha) (2011).

In addition to association with the life, numerous phayas are based on Buddhism as the life of the Isan people in the old days were tied to Buddhism intimately and they had a strong faith in Buddhism. Therefore, the local philosophers, both the clergy and the laity, borrowed the contents of phaya from Buddhist principles from the basic to advanced levels. Isan phaya includes these contents: karma, five precepts, the ten wholesome performances, the eight-fold path, the four sublime states of mind, the four basis for success, the six directions, the thirty-eight blessings and the four noble 
truths. The contents of the phaya were obviously influenced by Buddhism, especially to direct the new generations to concentrate on virtues, refrain from vices and live by the teachings of the Buddha. It can be concluded that the philosophy underlying this local wisdom is Buddhism. It is therefore worth analyzing.

Based on prior research, this present study had the following distinctions. First, no prior research has studied Isan phaya in terms of Buddhist cultural heritage and local wisdom, especially to see how the local Isan philosophers borrowed ideas from the original source or Tripitaka. Second, this present study analyzed Isan phaya how the original source was borrowed from the source literally and figuratively. Third and finally, this research study focused on the three common characteristics of existence, one of the essential Buddhist principles have never been studied before. This present study was, therefore, worth analyzing, with the following research question: How did the local Isan philosophers borrow ideas from Tripitaka, to compose Isan Phayas literally and figuratively? To answer this research question, the following was the purpose of the study.

\section{Purpose of the Study}

This study primarily aimed to analyze how the local Isan philosophers borrowed ideas from Tripitaka to compose Isan literally and figuratively, with a specific focus on the three common characteristics of existence, consisting of anicca, dukkha and anatta.

\section{Research Method}

This was a documentary study. The research procedure followed these three steps. First, the researchers explored how the local Isan philosophers borrowed ideas from Buddhism and invented Isan phayas on lifestyle. Second, the researchers analysed 252 Isan phayas that still exist and used by the local Isan people based on the study of Pornsavan Suvannasri on "An Analysis of phaya-Isan: Values, Existence and Transmission" to draw out the focal themes under the analysis (i.e. three common characteristics of existence), consisting of: anicca, dukkha and anatta. Finally, the verses in these three categories were analyzed to draw out the essence of the verses as stated in Tripitaka and draw the conclusion of the study.

\section{Results of the Study}

The analysis of the study on the focal themes under the study (i.e. three common characteristics of existence), consisting of anicca, dukkha and anatta. The results revealed that, literally and figuratively, the Isan phaya has borrowed from Tripitaka and presented the contents as they are in the original source for a didactic purpose to remind the local people to be aware of the nature of life according to the teachings of the Buddha, especially the impermanence of all things and suffering caused by this impermanence. All created Isan phaya verses aimed to remind the listeners that everyone is subject to impermanence which consists of these three common characteristics as follows: anicca, dukkha and anatta respectively.

1. On anicca or the condition that everyone and everything is limited to a certain duration and, consequently, liable to change and disappear, this characteristics is less obvious in Isan phayas than the other two ones and the contents of the phayas expressed the ultimately unsatisfactory nature of temporary states and things that are limited to a certain duration. Both pleasant and unpleasant experience is temporary and do not last long. We cannot deny either experience.

\section{“สุขทุกข์นี้ของกลางเทียมโลก บ่มีใผหลีกพ้นซิลงหันคู่คน"}

(Happiness and unhappiness is true to this world and no one can deny either.)

Both happiness and unhappiness are temporary like the following example. Things might change and maybe tomorrow we might have been crying. 


\section{"เพิ่นนั่งให้ โตอย่างนั่งหัว"}

(Do not laugh while others are crying.)

All things, either pleasant or unpleasant, are temporary. To avoid these temporary states and things, some phayas suggest some solutions, namely focusing on the present.

\section{“ห้างท้องใส่ไข่แลน"}

(Prepare for lizard eggs.)

In this phaya, it is likely that lizard eggs, or ไข่แลน, were chosen for literary purposes.

Homophone (i.e. ใส่ไข่) is chosen for a literary purpose. This phaya, however, implies that we should live on the present, focus on what is available and do not expect things or valuable things, to come because the expectations might not come true. Lizard eggs are something valuable for the local people but it is not worth expecting to get them and live a life on the expectation. The message might be very important as it was repeated as seen in the sample below:

$$
\begin{aligned}
& \text { "กรายไปหน้าหากินปลาหนองใหม่ } \\
& \text { หนองเก่านั้น แสนซิบ้อนก็บ่งม" }
\end{aligned}
$$

(Move on and on to look for fish in new ponds and ignore the old ones that are full of fish.)

Those who are not interested in what is available and always in pursuit of new things indefinitely might waste time as they already have what they are looking for. Figuratively, the ponds and fish refer to luck that people are already have but do not realize it and look for another one which might be beyond their reach or does not exist.

\section{“คาดซิได้บินมาคือนกเจ่า \\ คาดซิบ่ได้บินเจ้ยเจิดหนี"}

(If we will get a fortune that we expect, it will come to us just like a bird flying to us. If we won't, it flies away. Therefore, we should accept what will happen.)

\section{“ใผห่อนคองคอยถ้าคนตายซิต่าว คือ \\ ดังดาวอยู้ฟ้าคองได้ก็บ่มา"}

(No one is waiting for the dead to be revived like waiting for the stars in the sky that will never come down to the earth.)

We should not expect something that is impossible as it is a waste of time to do so and be focus on the present and what is available. In short, Isan phayas everyone and everything is limited to a certain period of time and this causes dukkha.

2. On dukkha or the condition that everyone and everything is unsatisfactory and cannot be relied on for true happiness. This this characteristics is the most obvious among the three. The phayas under this analysis revealed the dukkha is the truth of life.

\section{“สุขทุกข์นี้ของกลางเทียมโลก \\ บ่มีใผหลีกพ้นซิลงหันคู่คน"}

(Happiness and unhappiness is true to this world and no one can deny either.)

Happiness and unhappiness can be seen as merit and sin that we cannot deny and will follow us everywhere.

\section{“บุญบาปนี้เป็นคู่คือเงา \\ เงานั้นไปตามเฮาซู่ยามบ่มีเว้น"}

(Merit and sin are like the shadows that always follow us.)

Therefore, we should do the good things so that merit follows us and refrains from the bad things in order to keep distance from sin. The phayas include speaking, gossip, thinking before you speak, keeping promises, telling no lies, speaking no evils of others, saving, making merits, moderation, gratitude, forgiveness, maintaining good relationship between the relatives and friends. greed, lust, sacrifice, self-reliance, respect for the rights of others, promoting good rules of action, honor and dignity, codes of conduct, hospitality, anger control, unity, waste no 
time and money, leadership and refraining from all wrong doing and vices. The phayas also deal with the basic insight that life in this mundane world is dukkha, for example:

\section{“ฝูงหมู่หญิงชายส้วย สิบสามปีมีลูกลือแล้ว นักปราชญ์ถมแม่น้ำนทีกว้างขาดเขิน"}

(Teenagers of thirteen years old get married and have a baby. Even scholars cannot fix this problem.)

This phaya reflects the deterioration of social conditions that young men and women at the age of only thirteen years old have a family and a baby now despite of the fact that they are immature and unable to support themselves economically, socially and mentally. This situation is worsening even scholars who have the knowledge cannot fix the problem. Like the secular world, the religious world is in trouble as follows:

“ศาสนาสองพันห้ากรายมามันต่าง

สังฆะเจ้าวันมื้อบ่ถึกกัน"

(Buddhism now is not the same as it was two-thousand years ago. Sangha are in conflicts now.)

More subtly, some phayas explained the cause of dukkah, for example:

“ความอยากหยุ้งควายหลายโตดึงจ่อง
โตหนึ่งข้องงำคอม โตสองข้องง่าขาม
โตสามข้องง่ามี้ โตสี่ข้องหว้า
โตห้าข้องง่าบก โตหกข้องง่าแต้
ใผสิมาซอยแก้ ความน้อยจั่งสิไป”

(One's craving is like six buffalos pulling someone down. The six buffalos include visible objects, taste, smell, sound, touch and emotions. These six buffalos refer to ayatana. If one cannot control ayatana, life will get into trouble. All suffering is caused by ayatana. To refrain from suffering is to control ayatan. To control body, speech and mind is to control ayatana.)

Whoever, either in secular or religious worlds, clings to the six ayatana and craves to impermanent states and things is dukkha. Dukkha arises when we crave and cling to these impermanent states and changing phenomena. The clinging and craving condition leads to karma, which ties us to samsara or the round of death and rebirth. Craving includes kama-tanha, craving for sense-pleasures; bhava-tanha, craving to continue the cycle of life and death, including rebirth; and vibhava-tanha, craving to not experience the world and painful feelings. Samsara or the round of death and rebirth was conveyed in this phaya.

\section{“สงสารนี้เวียนตาย เวียนเกิด \\ คือมดไต่ขอบด้งเวียนแล้วคอบเลิง"}

(The recurrence of life, or repeated rebirth of dukkha, keeps everyone caught in samsāra, or the endless cycle of repeated rebirth of dukkha and dying again, is a circulation just as ants are moving around the edge of the tray to the original.)

The Dukkha can be confined and ceases when one disengages from craving and clinging and craving and clinging are confined and cease. The state that craving and clinging cease when no more karma arises and rebirth ends. Cessation is nirvana or the state that the mind is in peace and there is no permanent self or soul in living beings (anattā) so liberation of the mind from karma is the key to free oneself from dukkha.

3. On anattā, this characteristics is the least obvious among the three. Anattā, or nonself, is the condition that everyone and everything has no self-inherent entity and cannot be controlled. The condition arises when one follows the Buddhist path (e.g. the Four Noble Truths and the Noble Eightfold Path) to moksha, or liberation, and it starts when one disengages from craving and clinging to impermanent states and things which come and go. We cannot rely on anyone or anything, even ourselves as well as others that have long been adhered to and embedded in the culture of the northeast (e.g. ghost and spiritualism), as revealed in the following phayas. Therefore we cannot adhere to 
anyone or anything. The only true thing or way we can adhere to is Buddhism.

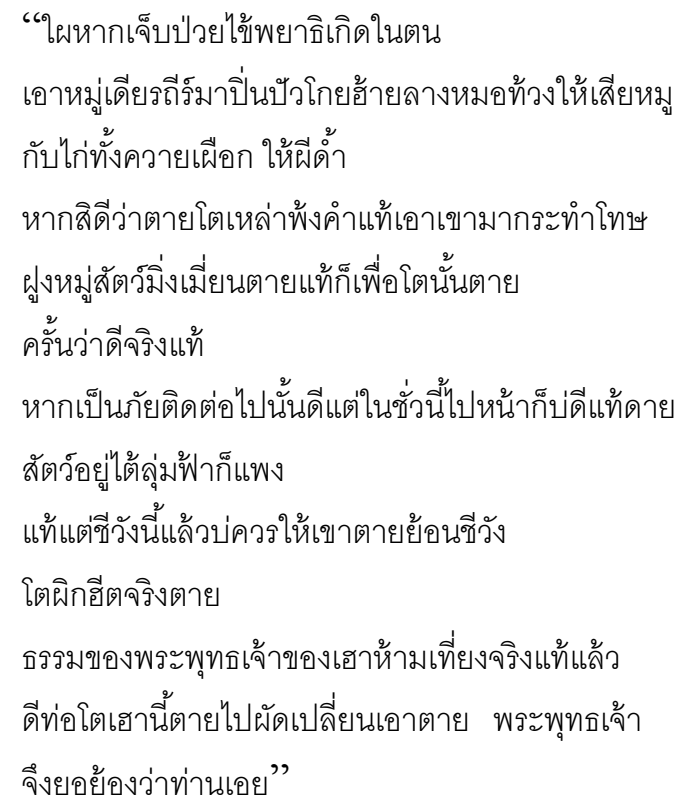

(If people who were sick by fever or illness seek help from a pagan for treatment, were asked by the pagan to kill animals (e.g. buffalos, pigs, chicken, etc.), considered such killing is properly reasonable, believed in those words and caused death to the cattle, this killing will never be beneficial to the sick people as those animals died to save them. Those animals love their lives, too. This is sinful and against the teaching of the Buddha, namely "do not kill." On the other hand, if they die to save those killed animals, the Buddha praised such a deed as great.)

“คนเฮานี้ ลางเทื่อดี ลางเทื่อฮ้าย ลางเทื่อมี

ลางเทื่อไฮ้ ลางเทื่อได้ซ้ำผิดเล่าพลอยเสีย

แม่นว่าเป็นผัวเมีย บ่เชื่อใจกันได้"

(We sometimes good, sometimes bad, sometimes rich, sometimes poor, sometimes getting but losing later. We cannot trust our husband/wife. Life is uncertain.)

“สิบชิ้นบ่ปานปลา แม่นว่าสิบพี่น้อง

ลุงป้าน้าอาก็บ่ปานพ่อและแม่

สิบพ่อแม่ก๋บ่ปานผัวและเมียแท้ แลสิบผัว
และเมียก็บ่ปานแก้วสามและครูบาอันสอนสั่งคลองนิพ พานนั้นแท้แล"

(Ten pieces of meat are not equal to one fish. Ten siblings and cousins are not equal to parents. Ten parents are not equal to spouses. Ten spouses are not equal to the three Gems (i.e. Buddha, Dharma and Sangha) and those who talked about Nirvana.)

“พระพุทธเจ้านี้เป็นเอกเอโกแท้ตายฝูงหมู่ผีสางสังสรร พสิ่งโยมย้อ ยอมไหว้หาอันใดมาเป็นที่พึ่งบ่มีแล้ว

มีแต่

คุณพระพุทธพร้อมพระธรรมเจ้าแลพระสงฆ์นั้นแล้ว

ใผบ่เอาใจเข้าในคลองพุทธบาฐสอนสั่งมานี้ฝูงหมู่โภยพ ยาธิ์ฮ้ายไหล เข้าหลั่งโฮมนั้นแล้ว

เห็นว่าโตสบายแล้วลืมคุณพุทธบาทเสียนั้น ชาติหน้าแลเหล่าได้เป็นฮ้ายบ่สังแท้แล้ว"

(Buddha is the only one that even ghosts respect and pray for so we can rely on Buddha, Dharma and Sangha. Those who do not abide by the teachings of the Buddha will suffer from all misfortunes and diseases. Those who find themselves comfortable and forget the kindness of Buddha will suffer from all evils in the next life. Therefore, everyone should follow the teachings of the Buddha.)

The messages of all the aforementioned phayas signify that we all need to adhere to and have a strong faith in Buddhism. The only pathway to the non-self is to follow the Buddhist path.

\section{Conclusion}

Five conclusions could be drawn from the results of the study.

First, in general, the local Isan philosophers borrowed ideas from Tripitaka to compose Isan phaya literally and figuratively as shown in the essences of the phaya.

Second, on anicca, the contents of the phaya under analysis expressed the ultimately unsatisfactory nature of 
temporary states and things that are limited to a certain duration.

Third, on dukkha, the phaya under this analysis revealed the individual and social aspects of dukkha as the truth of life, the condition that everyone and everything is unsatisfactory and cannot be relied on for true happiness.

Fourth, on anattā, the phaya specifically focused on disengagement from craving and clinging to impermanent and adherence to the Buddha path as the best way for disengagement.

Fifth and lastly that consistently convey the intended ideas using appropriate tone and style. Only a few numbers were adjusted for literary purposes (homophones).

It could be concluded that the Isan phaya has literally borrowed from Tripitaka and figuratively presented the contents as they are in the original source for a didactic purpose to remind the local people to be aware of the nature of life according to the teachings of the Buddha.

\section{Discussion}

The findings of this study were consistent with prior study (Bunnotok, 1984; Fakkong, 1987; Manyaporn, 1979; Mutramata, 1974; Tangkawee, 1985) that, like other local and traditional literature, Isan phaya greatly contributed to life on various aspects. This present study supported the study of Preecha (1985) that Isan phaya reflect the lifestyle of the local people. More importantly, the contribution of the phayas under this analysis was greater and more universal than the prior study as this study focused on the three common characteristics of existence (consisting of anicca, dukkha and anatta) which are concerned with the nature of life in all aspects. This study, therefore, rendered strong support to the study of Thanapaññõ (2011) that Isan phaya were drawn from Buddhist principles for didactic purposes and the phaya under this study were mostly drawn from Tripitaka.

\section{Implication of the Study and suggestion for further inquiry}

This reflects Isan local people's strong faith in Buddhism. Implications of this analysis reassure that Isan phaya may be a truly valuable heritage that should be passed on to the next generations for cultural and religious purposes. Therefore, further inquiry should analyze other Buddhist principles in Isan phaya.

\section{References}

Bunnotok, T. Local literature [in Thai]. Bangkok: Odeon Store, 1982.

Bunnotok, T. Feungwien: A study of the history and literature of Isan [in Thai]. Bangkok: Thammasat University, 1983.

Bunnotok, T. Methods for studying modern literature [in Thai]. Bangkok: Thaiwattanapanit, 1984.

Fakkong, S. Thai literature before Western influence [in Thai]. Bangkok: Karnsasana Publishing, 1987.

Manyaporn, K. Comparative literature [in Thai]. Bangkok: Pannakit, 1979

Mutramata, P. Thai literature: History and criticism [in Thai]. Ayutthaya: Tienwattana Publishing, 1974.

Phramahasopan Thanapañño (Settha). The Synthesis of Isan Proverbs into Buddhist Proverbs.

Mahachulalongkornrajavidyalaya University, 2010.

Pintong, P. Phayas: Traditional Isan Verse [in Thai]. Ubonrachatani: Siritham Publishing, 1985. 
Suvannasri, P. An Analysis of Phaya-Isan:

Values, Existence and Transmission. Chulalongkorn University, 2004.

Tangkawee, S. Knowledge and skill in language [in Thai]. Bangkok: Odeon Store, 1985. 